\title{
An Analysis of Dowry Practices and Its Religious Aspect in Rural Area of District Swat-Pakistan
}

\author{
Sajid Ali \\ Department of Rural Sociology, the University of Agriculture, Peshawar-Pakistan \\ Dr.Mussawar Shah \\ Chairman Department of Rural Sociology, The University of Agriculture, Peshawar-Pakistan \\ Dr.Naushad Khan \\ Assistant Professor Institute of Development Studies, The University of Agriculture Peshawar \\ Dr.Fazal Hanan \\ Chairman Department of Rural Sociology, University of FATA FR Kohat \\ Muhammad Tariq \\ Department of Rural Sociology, The University of Agriculture, Peshawar-Pakistan
}

\begin{abstract}
This study aimed at finding the association of dowry practices in Pakhtun culture (dependent variable) with religious aspect of dowry (independent variable). The study was conducted in three villages of District Swat, Khyber Pakhtunkhwa. A sample size of 331 respondents was selected through simple random sampling. Data was collected on a three level likert scale interview schedule. The association of study variables was tested by using chi-square teststatistics. The association of dowry practices in Pakhtun culture was found significant with dowry is the marriage phenomenon $(\mathrm{P}=0.001)$, religious scholars do not raise their voices against dowry $(\mathrm{P}=0.016)$, due to ignorance Islamic teaching. Dowry has taken a shape of religious obligations $(\mathrm{P}=0.000)$, understanding the teachings of Islam better understand the concept of dowry $(\mathrm{P}=0.000)$, clergies are making dowry a religious act due to their own vested interests $(\mathrm{P}=0.000)$, religious scholars have been failed to differentiate the religious aspect of dowry from cultural practices $(\mathrm{P}=0.000)$, religious bonds of marital life is replaced through socioeconomic relationships $(\mathrm{P}=0.000)$ and Pakhtun culture is highly reluctant to internalize religious values of dowry $(\mathrm{P}=0.000)$. To mitigate the social distress of dowry, misinterpretation of religious values, focusing on the socio-cultural dynamics were recommendations of the study.
\end{abstract}

Keywords: Analysis Aspect, Culture, Dowry, Religious

DOI: $10.7176 / \mathrm{JPCR} / 41-01$

\section{INTRODUCTION}

Dowry is actually a transfer or a portion of property from bride's family to bridegroom at the time of marriage.Dowry included not only cash payment rather also certain number of clothes for in-laws and other relatives. Dowry is usually consisted of number of things i.e. gold, car, motorbike, crockery, furniture, spoons, pillows, bedcovers, clothes etc. These items normally are transfer to bridegroom family at the time of marriage.(Haveripeth, 2013, Tazeen\& Ali, 2013 andNegi, 1997).It is very astonishing that dowry is supposed to continue and does not stop after marriages rather perpetuate after marriage as well. Nowadays dowry is not merely confined to property or cash but it also included the transfer from bride's family to that of bridegroom family in the form of jewelry, household items, appliances and vehicles i.e. car, motorbike etc. (Puri, 1999 \& Van,Willigen\&Channa, 1991 andPaul, 1986).Pakistan being an Islamic Republic; putting emphasis on execution cases on Islamic rules. However, there some of the zegious, where un-Islamic every rule and regulation in the state is based on rules prevail. Where here been kept restricted on culture basis and their legal and civil rights are curtailed in most parts of Pakistan. There are often associated to the prevalent customs and traditions. Jirga and punchaiat have made women plight more pathetic with rise in grievances and has reduced the social construction theories infective. Moreover, some other customs raja soyan of Indians society and adding a significant attachment and gifts giving have strength to the phenomenon of marriage in Hindu society with variations on class and caste basis (UN, 2011 Ibrahim, 2005Khattak, 2001 andSheel, 1999).

The perception or concept of dowry Jahez doesn't be present in Islam. It's clearly a cultural phenomenon that is showed or considered un-Islamic. Sharia doesn't make any overhead or expenses obligatory on the wife/wife's parents. Even the wedding expenses, it's suggested, are to be borne by the bridegroom or husband. Interestingly sufficient, just like any extra social immoral aimed against females, even in a wedded set up the husband as a man member of the household and not as a mate is often seen and to be one of the perpetrators or committers of delinquency. The males, who takes refuges, protection or safe place in Islam to explain their 
hatred and atrocity in the direction of women, intentionally forget the beautiful concept or idea of friendship as contemplated, in Quranbetween the male and a female (UN, 2011).The old custom and practices concerning wedding ceremony are totally dissimilar amongst the Muslim people and the Kalash. In this concern, the practice and ritual activities of the Muslim couple has been differently positioned and recognized. The marriage ceremonials for a Muslim pair are adhering to severe Islamic rules or laws and values. Equally, majority of the actions are initiated and followed by household members in consultation with seniors and in maximum of the cases; the decision is taken by them. The women are forbidden to claim for selecting her lifetime lover and such an act is treated as a stigma for the entire household. Dowry or bride amount is fixed and the husband collects the amount of spouse price in different styles, for instance property, currency amount, or any extra things as agreed and show willingness by the parties. On the other hand, it is very dangerous during the wedding proposal to look and detect the economic situation and social upright or standing of the husband because among the simple community, marriage is the only manner through which a male and female have their social and sexual rightfulness and agreement of connection or relationship in upcoming In the same way, any such dealing without the bonds of wedding are rejected or disallowed by Islam and is considered as adultery which is a punishable as wrongdoing (Naz, 2015).Under Islamic sharia females have rights to heritage both as daughters and as widows as well, but, divorced females enjoy no right to their mates or husbands' assets. Widows are to collect one eight of the assets or one fourth if they have no offspring's. Where the wedding was polygamous, this section is shared among all the wives or spouses. The providing for widows is the important priority.Under Islamic Law, a wife is eligible to inherit and to collect Maher, or dowry, on wedding. Maher is entirely the wife's assets and is intentional to give her economic security in the event of divorce. Further, by traditional custom a female doesn't inherit, and walwar is given or paid in place of Maher. Walwar is an amount of cash or assets paid by the bridegroom to the head of the wife's family. The value for walwar can be quite great and it is forbidden by formal law. This leaves the female in the wedding without right to inherit from her household or the economic safety envisioned in Shari's or civil code. In addition, the values of daughters to the household materialize at her wedding; later that she is of a little bit value to them.However, dowry is not sanctified as a religious necessity in Islam; many men claim that dowry is a religious custom or tradition originated by the creators or founders of the religions. In India, although forbidden by-law, the practice of dowry is very common. For non-Muslim in India mean Hindus, normally the daughter's household provides or gives dowry to her new spouse and his family(RDI, 2009, Naz, 2015). These reviews vividly depict a comprehensive explanation over woman results in the preamble of religious injunctions. However, the ground realities are in total repugnance, as a social and cultural explanations and meanings have been associated to dowry in Pakistan scenario with a conspicuous refection in the trait and fabrics of pakhtun culture keeping into consideration there paradigms shifts the present study is designed to explore the true reasons of their functional alterations.

\section{MATERIALS AND METHODS}

This study was carried out in three villages namely Hazara, Guljaba and Maloch in District Swat, Khyber Pakhtunkhwa, Pakistan. Total population (House hold heads) of potential respondents came out to be 2400 . For a population size of 2400 a sample size of 331 suffices as per criterion devised by Sekaran (2003). The study design was single-shot and data was collected through interview schedule covering both the variables. A conceptual framework was devised comprising of two study variables i.e. dowry practice in Pakhtun culture (Dependent Variable) and religious aspect (Independent Variable) (Table 1). For the measurement of study variables the attitudinal statements were pooled from the existing literature and three level likert Scale was constituted for each study variable.The indexed dependent variable (dowry practice in Pakhtun culture) was cross tabulated with independent variable (religious aspect) to measure the association between study variables. Chi-square test was used to test the level of association between these variables at bivariate Level.

$$
\chi^{2}=\sum_{i=1}^{r} \sum_{j=1}^{c} \frac{\left(O_{i j}-e_{i j}\right)^{2}}{e_{i j}}
$$

Table 1 Conceptual Frame Work

\begin{tabular}{|c|c|}
\hline Independent Variable & Dependent Variable \\
\hline Religious Aspect & Dowry Practice in Pakhtun Culture \\
\hline
\end{tabular}

\section{RESULTS AND DISCUSSION}

Frequency and Percentage distribution on the basis of Religious Aspect

Pashtun culture has totally overlapped the Islamic bonds and of life and has led to the persistent cultural values as sacred as religious regarding the dowry. It could be the due act repercussions of inabilities on part of these mal interpretation. However, Islamic scholars who also don't playing a vital role against dowry as phenomena have 
most to do anything with Islamic traits of life. Pashtun people double minded about dowry practice some people said its religious phenomena while the mostly misunderstood phenomena could be attributed to close similarities of the issue with inheritance.

Table.1. explained that majority of the respondents $55.3 \%$ expressed themselves that Dowry is the marriage phenomenon. Similarly, $42.0 \%$ were negated the statement, and $2.7 \%$ had no idea about it. Every religion has owned ways of marriage ceremonies and every wedding ceremony has undergone from one placed time to other, Most of the religious scholars have supported the dowry at the time of marriage However, Islam as religion has no any support to it rather a cultural obligation. These findings were also supported by (UN, 2011). Majority of the respondents $52.3 \%$ did not endorse the statement that dowry is a religious phenomenon rather than cultural. Similarly, $46.2 \%$ were supported the statement and $1.5 \%$ had neutral views about it. These findings emanated that local, had clear vision over dowry practices as cultural thanreligious. These findings were not supported by Theology, (1996) that dowry is a religious phenomenon rather than cultural. Dowry was made by cultural not by religions as prerogatives. Islam as religion has never educated in the practice of dowry. It was the ignorance part of local that they take it upon as religious and divine nature.

Furthermore, majority of the respondents $70.7 \%$ opined that religious scholars do not raise their voices against the evil practice of dowry. While, $26.0 \%$ expressed themselves otherwise and $3.3 \%$ did not express the views. Religious scholars or clergies interpretation of beliefs pertaining to practice do carry profound effects on the followers. However, whenever, these scholars have kept silence over any aspect of life has usually led to a scenario, has explained in his study that UN, (2011).

Similarly, majority of the respondents $77.3 \%$ supported the idea that due to ignorance Islamic teachings dowry has got a shape of religious obligations. Whereas, $17.2 \%$ had negated the statement and $5.4 \%$ were neutral views about it. Due to ignorance Islamic teachings dowry has got a shape of religious obligations and people has started do its practices due to persistent emphasis from culture it could be also attributed to the poor performance on part of religion leaders, that people had put a faith into a religion way of life. These findings were supported by (Theology, 1996). Majority of the respondents $80.1 \%$ supported the statement that Understanding the teachings of Islam better understand the concept of dowry.

In contrast, $16.0 \%$ had negated the statement and 3.9\% had neutral views about it. that understanding the teachings of Islam better understand the concept of dowry All the Islamic books are available in everywhere and taking input from there along with getting enrichment from religious scholars could lead to better understanding of dowry practices. A lack of education facilities the continuation of giving a dowry. Many Pakistani become greedy when they think about what a dowry can provide them. A Dowry is very bad thing and should be banned in all countries. There should be proper rules and laws about a dowry. Proper steps should also be taken to reduce this harmful disease in society. Young generation should talk to their parents about this issue and do their best to reduce this disease.

In addition, majority of the respondents $49.9 \%$ were negated the statement that clergies are making dowry a religious act due to their own vested interests. Similarly, $40.2 \%$ had negated the statement and $10.3 \%$ were neutral views about it. These findings explicitly explained that some religious scholars were not following the Islamic interpretation for their personal benefits and they were motivating people, towards giving dowry to their daughters at the marriage time it could be associated to their vested interests as both families, involved in marriage happily to them in cash and kinds such as gifts etc.

Furthermore, almost 59.5\% respondents were agreed the religious scholars have been failed to differentiate the religious aspect of dowry from cultural practices. While, $32.3 \%$ had negated the statement and $8.2 \%$ had no idea to express these findings had high degree of matching to the preceding findings. Likewise, majority of the respondents $69.8 \%$ reputed the statement that religious bonds of marital life is replaced through socioeconomic relationships in pakhtun culture while, $20.5 \%$ respondents supported the statement and 9.7\%did not say anything. It could be due to the prevalence of consistent change in cultural practices pertaining to marriage. These practices have comprehensively replaced the earlier references and started converting there to economic gains. Moreover, majority of the respondents $66.5 \%$ explained the statement that Paktun culture is highly reluctant to internalize religious values of dowry. Similarly $25.1 \%$ had negated the statement and $8.5 \%$ were neutral about it. These findings explicitly explained the respondents attribute over the miss interpretation of religion teachings and learning more from the cultural traits too deep in. 
Table 1 Religious Aspect Response About Dowry by Sampled Respondents in the Study Area

\begin{tabular}{|c|l|c|c|c|c|}
\hline S.No & Attribute & Yes & No & Uncertain & Total \\
\hline 1 & Dowry is the marriage phenomenon & $183(55.3)$ & $139(42.0)$ & $9(2.7)$ & $331(100)$ \\
\hline 2 & Dowry is a religious phenomenon rather than cultural & $153(46.2)$ & $172(52.3)$ & $5(1.5)$ & $331(100)$ \\
\hline 3 & $\begin{array}{l}\text { Religious scholars do not raise their voices against the } \\
\text { evil practice of dowry }\end{array}$ & $224(70.7)$ & $86(26.0)$ & $11(3.3)$ & $331(100)$ \\
\hline 4 & $\begin{array}{l}\text { Due to ignorance Islamic teachings dowry has been a } \\
\text { shape of religious obligations }\end{array}$ & $256(77.3)$ & $57(17.2)$ & $18(5.4)$ & $331(100)$ \\
\hline 5 & $\begin{array}{l}\text { Understanding the teachings of Islam better understand } \\
\text { the concept of dowry }\end{array}$ & $265(80.1)$ & $53(16.0)$ & $13(3.9)$ & $331(100)$ \\
\hline 6 & $\begin{array}{l}\text { Clergies are making dowry a religious act due to their } \\
\text { own vested interests }\end{array}$ & $133(40.2)$ & $164(49.9)$ & $34(10.3)$ & $331(100)$ \\
\hline 7 & $\begin{array}{l}\text { Religious scholars have been failed to differentiate the } \\
\text { religious aspect of dowry from cultural practices }\end{array}$ & $197(59.5)$ & $107(32.3)$ & $27(8.2)$ & $331(100)$ \\
\hline 8 & $\begin{array}{l}\text { Religious bonds of marital life is replaced through } \\
\text { socioeconomic relationships in Pakhtun Culture }\end{array}$ & $231(69.8)$ & $68(20.5)$ & $32(9.7)$ & $331(100)$ \\
\hline 9 & $\begin{array}{l}\text { Paktun Culture is highly reluctant to internalize } \\
\text { religious values of dowry }\end{array}$ & $220(66.5)$ & $83(25.1)$ & $28(8.5)$ & $331(100)$ \\
\hline
\end{tabular}

\section{Association Between Religious Aspect and Dowry Practices in Pakhtun Culture}

Dowry is usually practicing in marriage ostensibly embedded in local culture with assumption to be religious practiced as well. Pakhtun culture as one of the vibrant has also enriched with provision of dowry, either enriched from intimation with Hindu culture or high inclination to Islam, which empowered women in inheritance for the first times in the history of comparative religions. All of these efforts come up with sole aim of protecting the social and physical status of a woman soon after her marriage.

Table 2 disclosed Significant association $(\mathrm{P}=0.001)$ was found between Dowry is the marriage phenomenon and dowry practices in pakhtun culture. Dowry is one of the basic ingredients of marriage. It has got a shape as unchallengeable, bindings and did not give any excuse to escape. Through it is purely cultural in obligations however do practice it in the garbs of religion. They have taken support from s number religions quotations from Islam. Women share in inheritance has been distorted in providing them with dowries. The provision of dowry is misunderstood to be an religious practice (Noorie, 2010). While, a non-significant association $(\mathrm{P}=0.523)$ was established between dowry is a religious phenomenon rather than cultural and dowry practices in pakhtun culture. These findings clearly explained dowry with in the preamble of religion. Dowry, an India practice, has overshadowed the Islamic concept of mahr. Mahr is a predetermined of marriage to be honored by a weeding husband to his weeding wife at the time of marriage. It may include providing a sense of security and strength to this very union. Moreover, it is a sort of recognition; acquire from the relative and other well wishes as well (Noor, 2004, and Noorie, 2010). Correspondingly, a significant association ( $\mathrm{P}=0.016$ ) was confirmed between religious scholars do not raise their voices against the evil practice of dowry and dowry practices in Pakhtun culture. Religious misinterpretation has added to the people miseries as they pay more dowries by putting much stress burden on their relative economics. These findings were in support to Mehmood (2010). Who concluded that most of the people had anonym ace from religious scholars because they were never focus on resolving the dowry during their sermons in masques, madrasas, after offering the prayers and other religious occasions take jumakhutaba etc. They failed to confine the real face of Islam by distinguishing between religion and culture. It obligatory as dowry is dislike and dis owned by Islam and leading to security of relations between the marring families.

Whereas, a highly significant association $(\mathrm{P}=0.000)$ was found between due to ignorance of Islamic teachings dowry has been getting a shape of religious obligation and dowry practices in pakhtun culture. These findings were in support to the fore mentioned inferences. It's our responsibility to out religious scholars to explain the phenomena of dowry in the perspectives of Islam; ignorance to this end has multiplied the misaims of local. Understanding Islamic teachings based on Quranic interpretation in the shape of turjuma and explanation of Ahadiths could lead to reducing the distress of dowry in the local life. It is to mention that early ages of Islam has reported marriage as simple with lesser spending devoid of putting any unnecessary and unjustified economic burden over the marrying families (Kalanauri, 1999). Similarly, a highly significant association $(\mathrm{P}=0.000)$ was confirmed between understanding the teachings of Islam better understand the concept of dowry and dowry practices in pakhtun culture. These findings were in consequence to the above results. Majority of the people could turn the tables provided they assumed any practices against them and religion. That number of the families didn't aware about the misuses of dowry practice and still existence. Pakhtuns as a nation and culture could differentiate between jahez (An Islamic concept of share in property) and 
dowry. It has been concluded that those Muslims. Who, converted from Hinduism are more practicing the dowry. It could be attributed to aim inferences the Hinduism as religion and culture has upon it. However, it could not be in existence in the remaining majority Muslim countries. Basically, it is traced back as an ancient trait of Hinduism, which has the characteristics of the most primitive culture on the earth. Islam as a religion guarantees the daughters a legitimate right of share in the property of their parents in the shape of inheritance (Theology, 1996, and Kalanauri, 1986).

Correspondingly, a highly significant association $(\mathrm{P}=0.000)$ was established between clergies are making dowry a religious act due to their own vested interestsand dowry practices in pakhtun culture. Pakistan, like other theological states has the religion leaders a pivotal role to play. These religious leaders are primarily responsible for shaping and molding the behavior of the Muslims through sermons. Five times prayers a day leading the juma (Friday) prayers and offering funeral prayers are some of the occasions, seldom spared to address the Muslims. In addition, the marriage ceremony also necessitates him role to perform by performing the Nikah (Marriage bonds). All these circumstances have empowered a clergy to control and divert the Muslims. However, they failed to deliver a true marriage over dowry. Thus deliberate negligence has a strong associate to his vested interests.

Similarly, a high significant association $(\mathrm{P}=0.000)$ was confirmed between religious scholars have been failed to differentiate the religious aspect of dowry from cultural practicesand dowry practices in pakhtun culture. Islamic scholars better know about the misuses of dowry practice, however, could not address the followers to relate it to cultural backgrounds the Islamic laws and ways of life amply focused on giving women there rights. However, on the spot information reviewed by the researcher revealed that they did not receive any guidance about dowry from these religious leaders. Rather, most of the respondents believed it a provision staking about giving something's to daughter at the time marriage. Since the dowry is not culturally forbidden, it is spreading in pakhtun culture and has become a routine affaires of the society. It is enhancing because of the conducive environments which high degree of inclinations and emotional attachments of people. These reports were discovered by (Ahmad, and Kashem, 2015).

In the same way, a highly significant association $(\mathrm{P}=0.000)$ was found between religious bonds of marital life is replaced through socioeconomic relationships in Pakhtun culture and dowry practices in pakhtun culture. Pashtun cultures adjudge the religious bonds and they know everything of Islamic laws. However, following the phenomena of dowry has been measured to on the rapid rise are more inclined to demonstrate in dowry related practices. People attitude of displaying with reference to dowry was highly associated as a matter of prestige financial strength and social upward moment. Religion, through enjoying great deal of influence over people behaviors but the persistence of its practice could be related to the high degree of willing nous as a practicing ritual is indicative of the fact that locals still has deep faith in it. People have associated the happiness of both marrying partners with the practice of dowry demand from groom's family according the nature and amount of dowry is one of the explicit aspect of people belief in practicing dowry as reported by (Ahmed, and Kashem, 2015). Equally, a highly significant association $(\mathrm{P}=0.000)$ was established between Paktun Culture is highly reluctant to internalize religious values of dowry and dowry practices in pakhtun culture. Most of the Pashtuns seldom understood the dowry uses of and related practices (through the goggles of religion. Islamic knowledge is lacking either due to the poor performance in deliverance by religious scholars (Noorie, 2010) or they are reluctant to make it a point of debate. Such situation has mode dowry as an essential aspect for Muslim communities' with misuses, pains and agonies for the practicing families.

It's concluded from the above result that Islamic scholars didn't play their role in mitigating the evil practice of dowry. Pashtun people were found to high degree of inclination they were found to practicing dowry with great deal of display by making it an act of financial strength and social recognition from others. Religious leaders were found to be reluctant to explain the dowry practice as un-Islamic due to their vested interest. 
Table 3 Association Between Religious Aspect and Dowry Practices in Pakhtun Culture

\begin{tabular}{|c|c|c|c|c|c|c|}
\hline \multirow[t]{2}{*}{ Religious aspect } & \multirow[t]{2}{*}{ Perception } & \multicolumn{3}{|c|}{ Dowry Practices in Pakhtun Culture } & \multirow[t]{2}{*}{ Total } & \multirow{2}{*}{$\begin{array}{c}\text { Chi-Sqaure } \\
\text { (P-Value) }\end{array}$} \\
\hline & & Yes & No & Uncertain & & \\
\hline \multirow{3}{*}{$\begin{array}{l}\text { Dowry is the marriage } \\
\text { phenomenon }\end{array}$} & Yes & $139(76.0)$ & $44(24.0)$ & $00(0.00)$ & $183(100)$ & \multirow{3}{*}{$\begin{array}{l}X 2=17.865 \\
(0.001)\end{array}$} \\
\hline & No & 197(91.4) & $11(7.9)$ & $1(0.7)$ & $139(100)$ & \\
\hline & Uncertain & $9(100.0)$ & $00(0.00)$ & $00(0.00)$ & $9(100)$ & \\
\hline \multirow{3}{*}{$\begin{array}{l}\text { Dowry is a religious } \\
\text { phenomenon rather than } \\
\text { cultural }\end{array}$} & Yes & $122(79.7)$ & $30(19.6)$ & $1(0.7)$ & $153(100)$ & \multirow{3}{*}{$\begin{array}{l}X 2=3.210 \\
(0.523)\end{array}$} \\
\hline & No & $149(86.1)$ & $24(13.9)$ & $00(0.00)$ & $173(100)$ & \\
\hline & Uncertain & $4(80.0)$ & $1(20.0)$ & $00(0.00)$ & $5(100)$ & \\
\hline \multirow{3}{*}{$\begin{array}{l}\text { Religious scholars do } \\
\text { not raise their voices } \\
\text { against the evil practice } \\
\text { of dowry }\end{array}$} & Yes & $202(86.3)$ & $32(13.7)$ & $00(0.00)$ & $234(100)$ & \multirow{3}{*}{$\begin{array}{l}X 2=12.187 \\
(0.016)\end{array}$} \\
\hline & No & $67(77.9)$ & $18(20.9)$ & $1(1.2)$ & $86(100)$ & \\
\hline & Uncertain & $6(54.5)$ & $5(45.5)$ & $00(0.00)$ & $11(100)$ & \\
\hline \multirow{3}{*}{$\begin{array}{l}\text { Due to ignorance } \\
\text { Islamic teachings dowry } \\
\text { has been a shape of } \\
\text { religious obligations }\end{array}$} & Yes & $226(88.3)$ & $30(11.7)$ & $00(0.00)$ & $256(100)$ & \multirow{3}{*}{$\begin{array}{l}X 2=72.282 \\
(0.000)\end{array}$} \\
\hline & No & $46(80.7)$ & 11(19.3) & $00(0.00)$ & $57(100)$ & \\
\hline & Uncertain & $3(16.7)$ & $14(77.8)$ & $1(5.6)$ & $18(100)$ & \\
\hline \multirow{3}{*}{$\begin{array}{l}\text { Understanding the } \\
\text { teachings of Islam better } \\
\text { understand the concept } \\
\text { of dowry }\end{array}$} & Yes & $228(86.0)$ & $37(14.0)$ & $00(0.00)$ & $265(100)$ & \multirow{3}{*}{$\begin{array}{l}X 2=46.120 \\
(0.000)\end{array}$} \\
\hline & No & $43(81.1)$ & $10(18.9)$ & $00(0.00)$ & $53(100)$ & \\
\hline & Uncertain & $4(30.8)$ & $8(61.5)$ & $1(7.7)$ & $13(100)$ & \\
\hline \multirow{3}{*}{$\begin{array}{l}\text { Clergies are making } \\
\text { dowry a religious act } \\
\text { due to their own vested } \\
\text { interests }\end{array}$} & Yes & $123(92.5)$ & $9(6.8)$ & $1(0.8)$ & $133(100)$ & \multirow{3}{*}{$\begin{array}{l}X 2=42.999 \\
(0.000)\end{array}$} \\
\hline & No & $136(82.9)$ & $28(17.1)$ & $00(0.00)$ & $164(100)$ & \\
\hline & Uncertain & $16(47.1)$ & $18(52.9)$ & $00(0.00)$ & $34(100)$ & \\
\hline \multirow{3}{*}{$\begin{array}{l}\text { Religious scholars have } \\
\text { been failed to } \\
\text { differentiate } \\
\text { religious aspect of } \\
\text { dowry from cultural } \\
\text { practices }\end{array}$} & Yes & $177(89.8)$ & $19(9.6)$ & $1(0.5)$ & $197(100)$ & \multirow{3}{*}{$\begin{array}{l}X 2=72.017 \\
(0.000)\end{array}$} \\
\hline & No & $91(85.0)$ & $16(15.0)$ & $00(0.00)$ & $107(100)$ & \\
\hline & Uncertain & $7(25.9)$ & $20(74.1)$ & $00(0.00)$ & $27(100)$ & \\
\hline \multirow{3}{*}{$\begin{array}{l}\text { Religious bonds of } \\
\text { marital life is replaced } \\
\text { through socioeconomic } \\
\text { relationships in Pakhtun } \\
\text { Culture }\end{array}$} & Yes & $206(89.2)$ & $25(10.8)$ & $00(0.000$ & $231(100)$ & \multirow{3}{*}{$\begin{array}{l}X 2=58.268 \\
(0.000)\end{array}$} \\
\hline & No & $57(83.8)$ & $11(16.2)$ & $00(0.00)$ & $68(100)$ & \\
\hline & Uncertain & $12(37.5)$ & $19(59.4)$ & $1(3.1)$ & $32(100)$ & \\
\hline \multirow{3}{*}{$\begin{array}{l}\text { Paktun Culture is highly } \\
\text { reluctant to internalize } \\
\text { religious values of } \\
\text { dowry }\end{array}$} & Yes & $197(89.9)$ & $22(10.0)$ & $1(0.5)$ & $220(100)$ & \multirow{3}{*}{$\begin{array}{l}X 2=41.409 \\
(0.000)\end{array}$} \\
\hline & No & $66(79.5)$ & $17(20.5)$ & $00(0.00)$ & $83(100)$ & \\
\hline & Uncertain & $12(42.9)$ & $16(57.1)$ & $00(0.00)$ & $28(100)$ & \\
\hline
\end{tabular}

\section{CONCLUSIONS AND RECOMMENDATIONS}

The study depicted that dowry was found as a marriage phenomenon; however, religious scholars role pertaining to interpretation of marriage and dowry as Islamic or cultural was highly baffling. Most of the religious scholars had their own vested interest and did not play their true role in drawing marked differentiation regarding the dowry as cultural religious. Moreover, it was further discovered that marriage had taken the shape of a business. Where people had to invest up to utmost as they considered it a symbol of a attaining honor and prestige. In addition, there trends indicated about the marriage as a socio-economic activity rather fulfilling a sacred obligation based on social and religious demand of the society. A strong and dynamic role on part of the religious scholars arranging public debates to highlight thus emerging trend as detrimental to socio- cultural and religious bonds and state intervention with sand and specific embargo can practitioners of such practice to encourage a public discouragement in this regards, as policy recommendations.

\section{ACKNOWLEDGEMENT}

Sajid Ali create the idea while Dr.Musawar Shah supervised to him and help in research processing in the field while Dr.Naushad Khan help in writing the paper structure. Similarly Dr.Fazal Hanan and Muhammad Tariq help in proofreading and data collection in the field. 


\section{REFERENCES}

1. Ahmed. K. 2015.' Exploring the Socio-cultural Context of Dowry Practice in Bangladesh.'

2. Arunachalam, R and Logan, T., D. 2006. On the Heterogeneity of Dowry Movements.Cambridge: NBER Working Paper Series.

3. Chandra, paul 1986. Dowry and the position of women in India, new Dehli: inter-India publication.

4. Haveripeth, P.D. 2013. "Causes and consequences of dowry menace in India - a Criminological perspective", RIJS Vol.2 (2) (www.rierc.org)

5. Ibrahim \&Fariqa. 2005. Honor Killings under the Rule of Law in Pakistan, Master of Laws Thesis, Montreal: McGill University. [Online: web] Accessed on 9 Feb. 2016, URL: http://digitool.library.mcgill.ca/R/?func=dbin-jump-full \&object _id= 83953 \& local_base $=\mathrm{G}$ EN01MCG02

6. Kalanauri, 1986.'Islamic law and tradition of dowry and recovery through family courts.

7. Khan, Tariq Mehmood 2010 social-cultural determinants of women's empowerment in Punjab.Department of rural sociology, university of agriculture Faisalabad Pakistan.

8. Khattak, Saba. 2001." Women's and Empowerment," in AsadSayeed and Saba GulKhattak. Eds Women's Work and Empowerment Issue in an Era of Economic Liberalization: A case study of Pakistan's Urban Manufacturing sector. Islamabad: Pakistan Institute of Lab our Education and Research (PILER) and sustainable Development policy Institute (SDPI) 65-87.

9. M. S. Ali, Noorie, 2010.' Reality of Dowry.',

10. N.R. Nithya, 2013 "institutionalization of Dowry in India: social custom or modern Malaise". International journal of science and Research (IJSR), India online ISSN: 2319-7064.

11. Negi, 1997( c.f.Saravanan, S (2000) violence against women in India: A literature review) Instt. For Social Studies Trust Nithya, R. N.

12. Noor, Muhammad Jehanzeb (2004), Daughters of Eve: Violence against Women in Pakistan, Bachelor of Science Dissertation, Cambridge: Massachusetts Institute of Technology. of Oxford. Oxford. USA

13. Puri, D. 1999. "Gift of a daughter : change and continuity in marriage patterns among two generations of North Indians in Toranto and New Delhi". Unpublished Ph.D Thesis, Univ. of Toronto.

14. RDI, 2009."Women's Inheritance right to land property in south Asia."A report by the rurul development institute (RDI) for the world justice project December (2009).

15. Sharma, U. 1993. "Dowry in North India: Its Consequences for Women," in Family,Kinship and Marriage in India.Edited by Patricia Uberoi, New Delhi: OxfordUniversity Press.

16. Sheel, Ranjana. 1999. The Political Economy of Dowry. New Delhi: Manohar Publishers and Distributors.

17. Singh, J., P. 2005 Dowry in India: A search for new Social identity, The Eastern Anthropologist, 58(2) 199220. Singh, J. P.

18. Tambiah, S. J. (1973) "Dowry and Bridewealth and the Property Rights of Women in South Asia" G. Jack and J. T. Stanley, Eds., Bridewealth and Dowry. UK: Cambridge University Press Tambiah, Stanley J. TazeenSaeed Ali1,2, Gunnhildur Árnadóttir3, Asli Kulane3

19. Tazeen. S. A, 2013 "dowry practices and their negative consequences from a female perspective in Karachi, Pakistan: Department of community Health Social Sciences, Aga khan University, Karachi, Pakistan. Health, Vol.5, No 7A4, 84-91.

20. Theology, 1996 "payment of dowry and the Christian church" 128 Africa journal of evangelical theology 15.2

21. UN. 2011. "Forgotten Dowry: A socially endorsed form of violence in Pakistan", Accessed on 16 Oct. 2013, URL: http://www.sachet.org.pk/web/user files/File/Forgotten.pdf.

22. Van willingen, j \&channa. V.c. (1991). "Law, custom and crimes against women: the problem of dowry death in India". Human organization, 50, 369-377. 